\title{
PROMOTING PROFESSIONAL IDENTITY AMONG PRE-SERVICE ENGLISH TEACHERS THROUGH TEACHER CAMPS
}

\author{
Anderson Hidarto ${ }^{a}$, Chindy Christine ${ }^{b}$ \\ (ananderson.hidarto21@gmail.com, ${ }^{\mathrm{b}}$ chindychristine09@gmail.com) \\ ${ }^{a}$ Universitas Katolik Atma Jaya \\ Jalan Jenderal Sudirman 51, DKI Jakarta, Indonesia \\ ${ }^{b}$ Universitas Sanata Dharma \\ Mrican, Tromol Pos 29, DIY Yogyakarta, Indonesia
}

\begin{abstract}
With a mission to enhance the quality of EFL teachers, the Regional English Language Office (RELO) of the U.S. Embassy in Indonesia has conducted a pre-service teacher camp where practical teaching innovations are taught alongside reflective practices and the development of social and intercultural competences. This paper aims to examine how the participants, who are pre-service language teachers, perceived their professional identity as potential EFL educators after attending Camp EPIC and to what extent the program contributed to this process of professional identity formation. The study employed a mixed-methods survey where a total of 45 participants of Camp EPIC 2018 were purposively selected. They were asked to provide descriptions of themselves as teachers before and after the teacher camp, which were then analysed qualitatively using thematic analysis. As for the quantitative data, a set of thirty-three Likert-scale items were examined using Principal Component Analysis (PCA). The triangulated data indicated that the participants' perception was positively altered after the camp. While some mentioned that they were more resourceful and creative with teaching ideas, others showed a higher level of selfefficacy concerning their competence. These changes could be attributed to four major features of the camp: reflection, feedback, resource exploitation, and collaboration.
\end{abstract}

Keywords: perceptions, pre-service teachers, professional identity, teacher camp

DOI: http://dx.doi.org/10.15639/teflinjournal.v32i2/214-242 
The success of EFL instructions relies on many aspects, one of which is the role of the teachers who are in charge of the learning and teaching process. Furthermore, there is a positive correlation between teacher effectiveness and students' learning gains (Stronge et al., 2011), implying that it becomes crucial to educate teachers to become effective teachers. To pursue this goal, what is essential is how to provide sustainable and coherent teacher education programs, particularly for pre-service teachers.

Pre-service teacher education has long been aimed to aid student teachers in progressing in their professional and personal development. As Pop (2015) suggests, the first stage of such a program is designed to inculcate the pre-service teachers' understanding of the interconnectedness among subject-content knowledge, pedagogical knowledge, and attitude or personal qualities. At this stage, stakeholders of teacher education programs cannot neglect one recently prevalent concept that is argued to influence teachers' quality positively: professional identity.

As posited by Kudaibergenov and Lee (2020), EFL student teachers often experience tensions in their dual identities between being a person and being a professional. Such tensions, if not balanced well, may cause them to function less effectively and confidently in their job. Thus, when these novice teachers are made aware of their professional identities and trained how to juggle between their personal beliefs and the professional expectations imposed on them by the communities of practice where they work, this understanding of self-image can help identify their strengths and weaknesses as well as the strategies to tackle those challenges, resulting in better work performance. In addition, Irani et al. (2020) have pinpointed that assessing the process of teacher identity construction can provide teacher educators more insights into their student teachers, enabling them to design materials that can meet the needs in teacher education programs. These benefits are argued to have potentially positive effects on both teaching performance and learning outcomes (Afrianto, 2015; Ahmad et al., 2018). Given that, Afrianto (2015) further suggested that the formation of EFL educators' professional identity should commence as early as possible in teacher education programs.

Nevertheless, while the significance of professional identity of EFL preservice teachers has garnered considerable interest in formal teacher education (Abednia, 2012; Afrianto, 2015; Irani et al., 2020; Riyanti, 2017; Sardabi et al., 2018), the investigation of identity construction in language teacher training 
programs outside the formal sector is relatively scarce. Magnifying how formal teacher education courses should still be enriched, one study by Lomi and Mbato (2020) revealed how novice teachers still expressed some struggles during their first year of teaching experience despite having graduated from these programs. These new teachers also cited the necessity for a bridge between what is taught in formal teacher education and the actual in-service teaching, possibly in the form of non-formal training programs. In relation to the professional identity, training programs grounded on the tenets of situated learning (Lave \& Wenger, 1991) are potentially beneficial. Through collaboration and social interaction with their communities of practice, student teachers can gain access to activities where they critically reflect on their self-practices and constantly engage with the whole enterprise (Sarani \& Najjar, 2013), contributing to their ongoing process of identity construction. In the context of EFL pre-service teachers, one feasible yet underexplored type of non-formal programs to promote their professional identity is a teacher camp.

Among the pioneers of this idea is Camp EPIC - a pre-service teacher camp held in Indonesia by the Regional English Language Office (RELO) of the US Embassy. Camp EPIC serves as a ground where pre-service teachers from all over Indonesia are honing their teaching skills through various meaningful activities, such as collaborative micro-teaching, reflective sessions, and intercultural exchanges. These activities might be helpful for the continuous process of the pre-service teachers' professional identity formation in that they can reinterpret their experiences during the camp. Given its potential, the present study seeks to investigate how Camp EPIC has helped to mould its participants' professional identity by looking into their perceptions as English teachers after joining the camp through a mixed-methods study. Also, discussions on the camp's features and values are presented to provide guidelines for future practices.

\section{Professional Identity in Pre-Service English Teachers}

As illustrated in the review conducted by Beijaard et al. (2004), teachers' professional identity is a complex term that has been defined differently by many researchers. They pinpointed that a majority of the studies construed teacher's professional identity as "an ongoing process of integration of the 'personal' and "professional' sides of becoming and being a teacher" (p. 113), which in other words refers to the tacit relationship between personal, workplace and socio- 
cultural/policy dimensions (Day, 2012). As suggested by Canrinus et al. (2011), this volatile process is continuous and dependent on the interaction of the teachers with their work environment. In a similar vein, providing a scope of professional identity for pre-service English teachers, Afrianto (2015) relates the notion to their understandings of English teacher as a profession, the necessary characteristics or values that they are expected to have, and their perceptions of 'good and professional English teaching.' With this myriad of propositions, the present study condenses the concept of constructing professional identity into four major features: reflection (ongoing process), integration (person and context), adaptability (sub-identities), and active participation (agency) (cf. Beijaard et al., 2004).

As professional identity construction is seen as an ongoing process (Beijaard et al., 2004), the way pre-service teachers constantly perceive their experiences becomes important to consider. The need for reflective practice implies that teacher education not only concerns the idea of knowledge transmission but also deals with how to spur student teachers to keep learning from each other's experiences. Likewise, being reflective teachers entails acknowledging their commitment and motivation towards the job.

Another essential feature of professional identity pertains to how student teachers adopt both personal and professional characteristics of an effective teacher. The former includes the characteristics of teachers as a person: caring, respect, and fairness, interaction with students, enthusiasm, and confidence (Stronge, 2007). The latter can be observed through how they evaluate themselves as subject matter, pedagogical and didactical experts (Beijaard et al., 2000). It is noteworthy to examine the integration of the two values, which can further be subsumed under the construct of self-efficacy (Abednia, 2012).

Likewise, Beijaard et al. (2004) point out the idea of sub-identities, i.e., preservice teachers' adaptability to various teaching contexts and relationships. Student teachers are expected to be able to adjust themselves to different contexts in regards to teaching methodologies, curricula, or even cultures, i.e., their work environment (Canrinus et al., 2011). Equally important is how student teachers can interact with their students, colleagues, or authorities, particularly in cases of tensions, challenging circumstances, or conflicting expectations (Day, 2012).

The last component of professional identity is agency (Beijaard et al., 2004; Day, 2012), which denotes that both in-service and pre-service teachers should actively participate in professional development. As Coldron and Smith (1999) 
aptly noted, such active involvement can be manifested in the form of dialogue participation, resource exploitation, collaboration with others, community engagement, and other possible opportunities. This engagement will in turn help them enrich their professional expertise as EFL practitioners.

\section{Camp EPIC: A Pre-service English Teacher Camp}

Given the importance of professional identity, English teacher education programs should be designed to promote the pre-service teachers' identity development. At this juncture, a pre-service teacher camp like Camp EPIC can offer fundamental insights to such endeavour.

Camp EPIC is a two-week camp that gathers selected pre-service English teachers from provinces across Indonesia and East Timor. These pre-service English teachers are university students majoring in either English education, linguistics, and literature. During the camp, they are exposed to various innovative teaching approaches and English teaching tools through interactive activities, such as workshops, microteaching, and model teachings. They also engage in informal activities like games, singing, and cultural sharing, echoing the nature of Camp EPIC as a camp. In both formal and informal activities, participants are encouraged to actively engage in reflection and collaboration. In addition, the camp setting allows for a much more relaxed and supporting atmosphere than other typical teaching workshops. Upon the camp completion, the participants are required to cascade their knowledge in follow-up projects through replica workshops, which can be in the form of discussions, presentations, or teaching workshops at their home institutions.

Camp EPIC was first initiated following the practice of summer camps in the United States that has been proven effective in helping campers develop leadership and character-building skills and polish their self-confidence (W. S. Little, personal communication, May 2018). Specifically, English language immersion camps are found to result in significant benefits in terms of language improvement (Rugasken \& Harris, 2009; Wighting et al., 2006). However, while these camps are rather general in their scope, Camp EPIC exclusively targets pre-service English teachers as a promising group towards ELT development in Indonesia. As of the completion of the present study, there were a total of 164 student teachers from more than 40 higher education institutions who had joined the program. Furthermore, these participants contributed to their community by 
holding replica workshops, which had been attended by over 3,000 educators across provinces in Indonesia, signifying the multiplier effect of the program.

As informed by W. S. Little from RELO Jakarta, the concept of Camp EPIC revolves around its abbreviation: Empowered, Prepared, Inspired, and Connected. Empowering the participants, Camp EPIC endeavours to provide intensive pedagogical skill-building activities in an interactive and relaxed camp setting, such as communicative classroom innovations, games, songs, classroom management techniques, cultural information, and other resources. Even more significant is the fact that they are given chances to learn directly from both native English teachers and local ELT experts. Next, campers are prepared by being engaged in much collaborative work where they plan lessons, conduct micro-teaching sessions, do outdoor activities, and exchange feedback and ideas. Reflective sessions where they learn from their own experiences and others' experiences are likewise an integral part of Camp EPIC.

Campers, through this interaction with some ELT experts as well as fellow pre-service teachers across the archipelago, are led to get inspired by garnering insights from each other. They are made aware of diverse teaching practices in different socio-cultural contexts, which is a form of international and intercultural exchange (Walters et al., 2009). Lastly, resonating with its primary objective of building a community of teachers, Camp EPIC strives to connect the participants with similar passionate educators in a professional network even after the camp is over.

These four EPIC principles appear to correspond to the concept of situated learning (Lave \& Wenger, 1991), which postulates that effective learning can take place when learners engage in social interactions with experts and fellow learners in a community of practice. Through this apprenticeship, they are said to transition from novices to experts by critically reflecting on their preestablished competence and collaboratively constructing their learning experiences. The interplay between the learners' competence and learning experience in communities of practice, as noted by Wenger (2000), is inextricable to their identities. As Camp EPIC potentially serves as a fertile ground for the cultivation of communities of practice among the pre-service English teachers, it is intriguing to examine how the teacher camp has influenced their professional identity. 


\section{METHOD}

The current study involved 53 pre-service teachers across Indonesia who participated in Camp EPIC 2018 held in Surabaya for two weeks. The data were compiled using a convenient sampling technique since the research focused on evaluating one single program and the respondents were the most recent participants of the program. Of the 53 targeted respondents, 45 campers $(84.9 \%)$ filled out the questionnaire, comprising of 20 males (44.4\%) and 25 females $(55.6 \%)$. All of them were university students in their last year of study when they joined the program, and they already had some teaching experience as an intern, volunteer, tutor, or school teacher before the camp. To ensure their anonymity, each participant was represented by the letter ' $S$ ' plus a number; for example, S1 stands for 'Student Teacher 1'.

This study attempted to gather both quantitative and qualitative data through an online questionnaire distributed to the participants. The questionnaire consists of thirty-three Likert-scale items of five scales (strongly disagree to strongly agree) and four open-ended questions. The items were developed based on the constructs of professional identity by Beijaard et al. (2004), and some were also adopted from Abednia (2012) and Stronge (2007). While the quantitative data highlighted how the campers perceived themselves after the camp, the qualitative ones further shed light on how the program features led to the shaping of their perceptions.

There were two sections in the questionnaire: background information and the main survey. The first section was used to elicit general information about the participants' teaching experience and their description of themselves as English teachers before and after the program, which represented the participants' pre- and post-camp perceptions. Following this was the main survey, divided into four sections of professional identity elements: reflection, integration, adaptability, and active participation. Each category consisted of eight to ten Likert-scale items with an ensuing open-ended question. These follow-up questions were aimed to ask the participants which sessions of the teacher camp significantly influenced their four aspects of professional identity and the respective reasons. To avoid acquiescence bias, some items were made negative so that the respondents had some time to think before answering the questions. All the questionnaire items were constructed using English, to which the participants also responded in English. 
In addition, a pilot test was administered to previous EPIC campers who are currently in-service teachers to ensure the validity and reliability of the instrument. Content and face validity judgment was provided by EFL professionals, while its reliability was counted using the parameter of CronbachAlpha $(\alpha)$ with a value above 0.7 considered desirable (Hair et al., 2014). Based on the comments and statistical analyses, some ambiguous items were either revised or removed to avoid confusion and boost the reliability factor. During the actual data collection, both quantitative and qualitative data were collected concurrently using the revised version of the questionnaire.

The questionnaire was distributed one week after the program concluded, and as the participants came from various provinces in Indonesia, it had to be distributed online using Google Form. It is worth noting that the two researchers were the camp counsellors during the program, who were primarily responsible for chaperoning the participants. However, the potential bias was mitigated in that the respondents were informed that the questionnaire did not require them to evaluate the program, let alone any individual counsellors or facilitators. Rather, they were instructed to focus on their perceptions of their own professional identity. In the questionnaire information sheet, the respondents were also made aware that their responses were not to be shared with the camp organizers, encouraging them to respond honestly.

The participants' responses were then analysed sequentially using concurrent triangulation, where outcomes of the research can be enhanced by mixing quantitative and qualitative data, which were examined independently and later merged to address the research questions (Creswell, 2011). First, campers' self-descriptions in the background information were scrutinized to identify the general perception of their teacher identity before and after the program. This process was conducted using the Thematic Analysis framework (Braun \& Clarke, 2006), wherein meaningful codes (i.e., sub-categories) were initially deduced from the important key phrases in the responses, and their occurrences were then counted. This qualitative data later served to support the quantitative findings of the survey.

The quantitative data were analyzed using descriptive statistics, and as the variable of professional identity subsumes several sub-scales, it was broken down into more specific and observable components through Principal Component Analysis (PCA), one method of dimension reduction to reinforce the rigor of the questionnaire. Afterwards, some key features in the responses to the 
open-ended questions in each category were coded to identify which elements of Camp EPIC stood out in affecting the participants' new identity perception. In this case, the responses were quoted verbatim from the participants' responses to these open-ended questions. Finally, both quantitative and qualitative data were triangulated to address the issue in hand: Camp EPIC's roles in shaping the preservice English teachers' professional identity.

\section{FINDINGS AND DISCUSSION}

\section{Findings}

To achieve the research objectives, the results are divided into three sections based on the data triangulation. First, qualitative analysis of the participants' precamp self-description is presented, followed by a combination of qualitative and quantitative analyses of their post-camp perception of themselves. Hereafter, some important features of Camp EPIC are pointed out in relation to the change in the respondents' perception of their professional identity.

\section{Pre-Camp Perceptions}

Before joining Camp EPIC, the participants had already had some teaching experiences in various contexts, such as internships, volunteering, or language courses. However, based on the data of self-descriptions, a vast majority of the participants still cast doubt on their competence as English teachers, denoting that most of them harboured negative perceptions of themselves in regards to their identity as EFL teachers. Figure 1 and Table 1 illustrate the three emerging themes that the campers $(\mathrm{N}=45)$ mentioned in the descriptions.

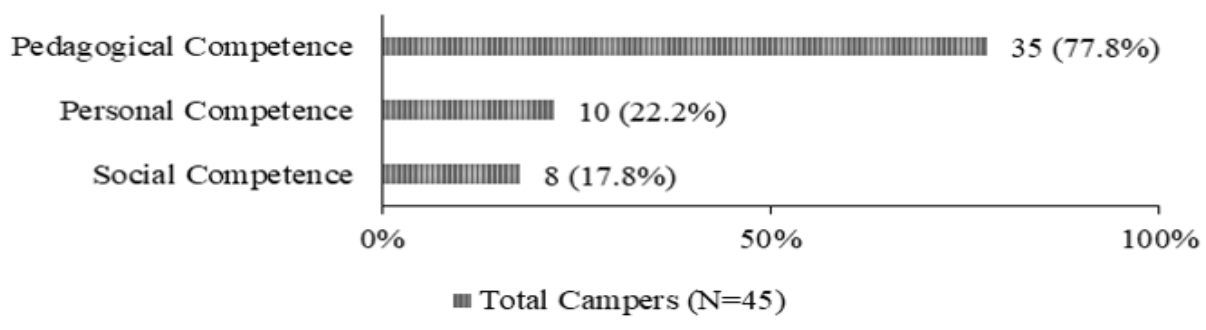

Figure 1. Campers' Perceptions on Their Problems as Teachers before Camp EPIC 
Hidarto \& Christine, Promoting Professional Identity Through Teacher Camps 223

Table 1. Details of Campers' Perceived Problems

\begin{tabular}{|l|l|c|}
\hline Category & Sub-Category & n \\
\hline \multirow{4}{*}{ Pedagogical Competence } & Innovative teaching ideas/resources & 30 \\
\cline { 2 - 3 } & Students' enthusiasm & 12 \\
\cline { 2 - 3 } & Classroom management & 9 \\
\cline { 2 - 3 } & Lesson planning & 5 \\
\hline \multirow{3}{*}{ Personal Competence } & Confidence and self-efficacy & 8 \\
\cline { 2 - 3 } & Job motivation and commitment & 3 \\
\hline \multirow{3}{*}{ Social Competence } & Interaction with students & 4 \\
\cline { 2 - 3 } & Work pressure & 2 \\
\cline { 2 - 3 } & Awareness of real teaching practice & 2 \\
\hline
\end{tabular}

Figure 1 shows that 35 campers (77.8\%) expressed concerns over their pedagogical competence, with most of them acknowledging problems with how to come up with creative teaching ideas or resources as can be seen in Table 1 . Representative of most of the responses is one put forth by S6, who believed that she still lacked teaching ideas despite her teaching experience.

Before joining Camp EPIC 4, I saw myself as a teacher who'd like to create fun and engaging activities in which the students would not feel burdened or pressured to study. However, I was still lack of teaching ideas (S6).

Some others mentioned problems in lacking teaching strategies (S4, S19), not being able to incorporate interesting activities like games and songs into their lessons (S26, S27, S35), or sticking to their "old and conventional" teaching methods (S5, S28). This type of response led to further problems such as the inability to ignite students' interest, with many stating that their lessons were usually boring (S3, S25) as well as issues related to classroom management (S3, S7) and lesson planning (S14).

Accordingly, a few campers felt that they did not demonstrate adequate personal $(22.2 \%)$ and social $(17.8 \%)$ competences. For instance, some considered themselves "a weak teacher" (S2, S39), indicating their low sense of confidence and self-efficacy. Meanwhile, others admitted having difficulty in identifying students' characteristics (S8), or getting frustrated with all the burdens in the teaching profession (S13); the latter was noticeable from her statement: 
I feel so frustrated because to be a teacher, we have to be able to make a lesson plan that is so complicated in a short time. Then, we are required to create fun activities related to our material and language skill in the teaching-learning process in order to attract students' attention. Sometimes, it makes us as a teacher feel stress (S13).

\section{Post-Camp Perceptions}

Based on the post-camp self-descriptions, the campers explained that they had some improvements after the program. The details are presented in Figure 2 and Table 2, which show the number and percentage of participants indicating each competence and sub-competences as the aspects they made improvement in after the camp.

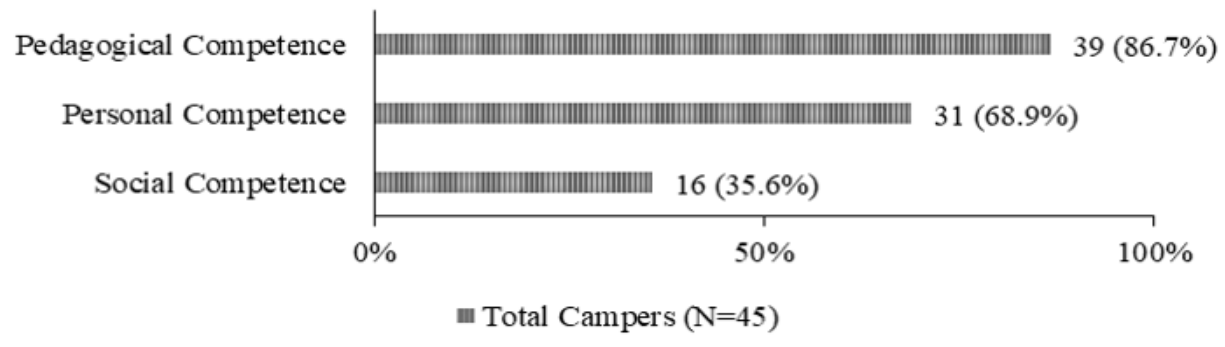

Figure 2. Campers' Perceived Improvement after Camp EPIC

Table 2. Details of Campers' Perceived Improvement

\begin{tabular}{|l|l|c|}
\hline Category & Sub-Category & n \\
\hline \multirow{4}{*}{ Pedagogical Competence } & Innovative teaching ideas/resources & 29 \\
\cline { 2 - 3 } & Lesson planning & 17 \\
\cline { 2 - 3 } & Students' enthusiasm & 12 \\
\cline { 2 - 3 } & Classroom management & 9 \\
\hline \multirow{4}{*}{ Personal Competence } & Confidence and self-efficacy & 19 \\
\cline { 2 - 3 } & Job motivation and commitment & 15 \\
\cline { 2 - 3 } & Being reflective & 7 \\
\hline \multirow{3}{*}{ Social Competence } & Interaction with students & 8 \\
\cline { 2 - 3 } & Community involvements & 6 \\
\cline { 2 - 3 } & Awareness of real teaching practice & 5 \\
\hline
\end{tabular}


The data show that more campers felt that they had some improvements in their pedagogical, personal, and social competences. Figure 2 indicates that a large number of campers (86.7\%) deemed themselves better teachers in how they dealt with class-related issues. For example, more campers affirmed that they could integrate a variety of teaching strategies into their lessons (S3, S4, S13, $\mathrm{S} 29$ ), and became more aware of the best practice of lesson planning (S13, S16, S19). The description of S32 was the main highlight of the positive change:

After joining Camp EPIC, I am now more confident when I teach my students in a classroom. I also have some new ways to engage my students to be more active in the learning process so my classes are more interesting and fun (S32).

More pre-service teachers also stated that they became more confident and enthusiastic about teaching (S13, S43) while remaining open-minded to learning opportunities. After joining the camp, they realized the importance of reflective practice, i.e., learning from their own experiences and others' (S17, S33, S40). What is more, several campers were inspired to share their knowledge with their community to level up the EFL teaching quality in their regions (S2, S22), as exemplified below.

I am now a teacher with more strength and knowledge of teaching and prepared to share knowledge to others especially my members of voluntary teachers in my community (S2).

Correspondingly, the questionnaire results show promising changes in the campers' perceptions about their competence. Table 3 demonstrates the means of their responses for each variable of professional identity.

Table 3. Overall Questionnaire Results (Post-Camp Perceptions)

\begin{tabular}{|c|c|c|c|c|c|}
\hline Category & Reflection & Integration & Adaptability & $\begin{array}{c}\text { Active } \\
\text { Participation }\end{array}$ & Total \\
\hline Means & 4.47 & 4.45 & 3.86 & 4.51 & 4.31 \\
\hline SD & .27 & .39 & .40 & .43 & .31 \\
\hline$A$ & .71 & .71 & .74 & .86 & .89 \\
\hline
\end{tabular}

The overall responses indicate a positive perception of campers towards their professional identity $(\bar{x}=4.31, \mathrm{SD}=.27)$ in relation to their participation in the program. Moreover, such a positive view is observable in each sub-scale, with the idea of reflection regarded as the most favourable $(\bar{x}=4.47, \mathrm{SD}=.27)$. 
On the other hand, while the notion of adaptability stands at the lowest value $(\bar{x}=$ $3.86, \mathrm{SD}=.40$ ) compared to others, it remains above the positive continuum of perception. The findings imply that Camp EPIC influences how the participants conceive their identity as English teachers in a positive way. In other words, Camp EPIC has successfully become one of many phases that help sustain their ongoing process of professional identity construction. The data likewise show that the reliability for each sub-scale indeed exceeds the desirable threshold of 0.7 (Hair et al., 2014): reflection $(\alpha=.71)$, integration $(\alpha=.71)$, adaptability $(\alpha=$ $.74)$ and active participation $(\alpha=.86)$.

Regarding the findings, it is necessary to scrutinize and categorize the specific elements of the sub-scales into several observable components through the principal component analysis (PCA). Based on the PCA with Kaiser criterion (Field, 2009), each major sub-scale is composed of two or three particular themes (see Table 4).

Table 4. Summary of Principal Component Analysis (PCA)

\begin{tabular}{|c|c|c|c|c|c|}
\hline Sub-Scale & $\begin{array}{l}\text { Specific Components } \\
\text { (Factors) }\end{array}$ & $\mathbf{M}$ & SD & $\begin{array}{l}\text { Eigen } \\
\text { value }\end{array}$ & $\begin{array}{c}\% \text { of } \\
\text { Variance }\end{array}$ \\
\hline \multirow{7}{*}{ Reflection } & $\begin{array}{l}\text { Job motivation and } \\
\text { commitment }\end{array}$ & 4.53 & .60 & 2.99 & 37.46 \\
\hline & $\begin{array}{l}\text { After attending Camp } \\
\text { EPIC, I am sure that } \\
\text { teaching has become part } \\
\text { of my personal life. }\end{array}$ & 4.60 & .54 & & \\
\hline & $\begin{array}{l}\text { - After Camp EPIC, I am } \\
\text { sure of my decision to } \\
\text { become an English teacher } \\
\text { in the future. }\end{array}$ & 4.60 & .69 & & \\
\hline & $\begin{array}{l}\text { I develop a strong passion } \\
\text { in the teaching world. }\end{array}$ & 4.40 & .58 & & \\
\hline & Reflective skills & 4.46 & .60 & 1.23 & 15.49 \\
\hline & $\begin{array}{l}\text { I feel the need to learn } \\
\text { from my past teaching } \\
\text { experiences. }\end{array}$ & 4.60 & .62 & & \\
\hline & $\begin{array}{l}\text { - I can explain to others } \\
\text { what I think about my }\end{array}$ & 4.27 & .58 & & \\
\hline
\end{tabular}


Hidarto \& Christine, Promoting Professional Identity Through Teacher Camps 227

\begin{tabular}{|c|c|c|c|c|c|}
\hline Sub-Scale & $\begin{array}{l}\text { Specific Components } \\
\text { (Factors) }\end{array}$ & $\mathbf{M}$ & SD & $\begin{array}{l}\text { Eigen } \\
\text { value }\end{array}$ & $\begin{array}{c}\text { \% of } \\
\text { Variance }\end{array}$ \\
\hline & $\begin{array}{l}\text { teaching performances in } \\
\text { either oral or written form. }\end{array}$ & & & & \\
\hline & $\begin{array}{l}\text { I feel that my teaching } \\
\text { knowledge (teaching } \\
\text { practicum, studies, } \\
\text { activities, experiences) still } \\
\text { should be improved. }\end{array}$ & 4.80 & .40 & & \\
\hline & $\begin{array}{l}\text { I can now evaluate my } \\
\text { teaching ability (skills and } \\
\text { knowledge) by myself. } \\
\end{array}$ & 4.04 & .80 & & \\
\hline & $\begin{array}{l}\text { - When my teaching is not } \\
\text { successful, I try to reflect } \\
\text { on what is wrong. }\end{array}$ & 4.60 & .58 & & \\
\hline \multirow{8}{*}{ Integration } & Personal characteristics & 4.60 & .53 & 3.51 & 31.94 \\
\hline & $\begin{array}{l}\text { I believe I can maintain } \\
\text { my professional roles as a } \\
\text { teacher while being } \\
\text { friendly. } \\
\end{array}$ & 4.66 & .59 & & \\
\hline & $\begin{array}{l}\text { After joining the program, } \\
\text { I describe myself as an } \\
\text { enthusiastic teacher. }\end{array}$ & 4.51 & .51 & & \\
\hline & $\begin{array}{l}\text { - Camp EPIC helps me instil } \\
\text { confidence in myself as a } \\
\text { teacher. }\end{array}$ & 4.62 & .49 & & \\
\hline & Professional traits & 4.37 & .68 & 1.26 & 11.45 \\
\hline & $\begin{array}{l}\text { - Camp EPIC changes my } \\
\text { views of how a 'good and } \\
\text { professional' teacher is. }\end{array}$ & 4.76 & .48 & & \\
\hline & $\begin{array}{l}\text { I believe I can create a } \\
\text { supportive and warm } \\
\text { classroom climate. }\end{array}$ & 4.07 & 1.07 & & \\
\hline & $\begin{array}{l}\text { I believe that I can } \\
\text { provide my students }\end{array}$ & 4.29 & .59 & & \\
\hline
\end{tabular}


228 TEFLIN Journal, Volume 32, Number 2, July 2021

\begin{tabular}{|c|c|c|c|c|c|}
\hline Sub-Scale & $\begin{array}{l}\text { Specific Components } \\
\text { (Factors) }\end{array}$ & $\mathbf{M}$ & SD & $\begin{array}{l}\text { Eigen } \\
\text { value }\end{array}$ & $\begin{array}{c}\% \text { of } \\
\text { Variance }\end{array}$ \\
\hline & $\begin{array}{l}\text { meaningful feedback for } \\
\text { their work. }\end{array}$ & & & & \\
\hline & $\begin{array}{l}\text { I believe I have the decent } \\
\text { competence to become a } \\
\text { qualified English teacher. }\end{array}$ & 4.36 & .57 & & \\
\hline \multirow{10}{*}{ Adaptability } & $\begin{array}{l}\text { Adapting to } \\
\text { materials/methodologies }\end{array}$ & 4.12 & .72 & 1.07 & 10.73 \\
\hline & $\begin{array}{l}\text { I can adopt the teaching } \\
\text { methodologies that I learn } \\
\text { in Camp EPIC for my } \\
\text { own English classrooms. }\end{array}$ & 4.47 & .63 & & \\
\hline & $\begin{array}{l}\text { I can use my own teaching } \\
\text { methods that meet the } \\
\text { curriculum demands. }\end{array}$ & 3.76 & .80 & & \\
\hline & $\begin{array}{l}\text { Adapting to different } \\
\text { relationships }\end{array}$ & 3.71 & .75 & 1.83 & 18.29 \\
\hline & $\begin{array}{l}\text { I can easily introduce and } \\
\text { apply new teaching } \\
\text { innovations at my } \\
\text { teaching institution. }\end{array}$ & 4.00 & .64 & & \\
\hline & $\begin{array}{l}\text { I can adapt well to } \\
\text { different kinds of students } \\
\text { at my teaching institution }\end{array}$ & 3.62 & .78 & & \\
\hline & $\begin{array}{l}\text { I can effectively cooperate } \\
\text { with my colleagues at my } \\
\text { teaching institution. }\end{array}$ & 3.51 & .82 & & \\
\hline & $\begin{array}{l}\text { Adapting to different teaching } \\
\text { contexts }\end{array}$ & 3.85 & .63 & 3.70 & 37.04 \\
\hline & $\begin{array}{l}\text { I can adapt well to the } \\
\text { teaching culture of my } \\
\text { teaching institution. }\end{array}$ & 4.00 & .56 & & \\
\hline & $\begin{array}{l}\text { I can easily resolve } \\
\text { conflicts when my } \\
\text { expectations do not match }\end{array}$ & 3.78 & .67 & & \\
\hline
\end{tabular}


Hidarto \& Christine, Promoting Professional Identity Through Teacher Camps 229

\begin{tabular}{|c|c|c|c|c|c|}
\hline Sub-Scale & $\begin{array}{l}\text { Specific Components } \\
\text { (Factors) }\end{array}$ & $\mathbf{M}$ & SD & $\begin{array}{l}\text { Eigen } \\
\text { value }\end{array}$ & $\begin{array}{c}\% \text { of } \\
\text { Variance }\end{array}$ \\
\hline & $\begin{array}{l}\text { with those of my } \\
\text { colleagues or the } \\
\text { authorities. }\end{array}$ & & & & \\
\hline & $\begin{array}{l}\text { I can easily deal with } \\
\text { assigned duties different } \\
\text { from my preferences. } \\
\end{array}$ & 3.78 & .67 & & \\
\hline & $\begin{array}{l}\text { I can adapt easily to } \\
\text { educational changes that } \\
\text { might take place at my } \\
\text { teaching institutions (e.g. } \\
\text { curriculum, structural } \\
\text { organization, } \\
\text { responsibility). }\end{array}$ & 3.82 & .61 & & \\
\hline \multirow{5}{*}{$\begin{array}{c}\text { Active } \\
\text { Participation }\end{array}$} & Active learning \& inquiry & 4.61 & .61 & 4.48 & 49.79 \\
\hline & $\begin{array}{l}\text { I feel more motivated to } \\
\text { get involved in teacher } \\
\text { development programs, } \\
\text { e.g. seminars, teacher } \\
\text { training, online courses. }\end{array}$ & 4.60 & .58 & & \\
\hline & $\begin{array}{l}\text { I feel the need to always } \\
\text { look for resources to } \\
\text { improve my teaching } \\
\text { activities. }\end{array}$ & 4.67 & .52 & & \\
\hline & $\begin{array}{l}\text { I am willing to implement } \\
\text { many different teaching } \\
\text { approaches instead of } \\
\text { adhering to one single } \\
\text { approach. }\end{array}$ & 4.47 & .76 & & \\
\hline & $\begin{array}{l}\text { I do not hesitate to ask for } \\
\text { advice and suggestions } \\
\text { from the 'relevant others' } \\
\text { (researchers, policy } \\
\text { makers, school } \\
\text { administrators, etc). }\end{array}$ & 4.51 & .76 & & \\
\hline
\end{tabular}




\begin{tabular}{|c|c|c|c|c|c|}
\hline Sub-Scale & $\begin{array}{c}\text { Specific Components } \\
\text { (Factors) }\end{array}$ & $\mathbf{M}$ & SD & $\begin{array}{l}\text { Eigen } \\
\text { value }\end{array}$ & $\begin{array}{c}\% \text { of } \\
\text { Variance } \\
\end{array}$ \\
\hline & $\begin{array}{l}\text { Feedback, comments or } \\
\text { criticisms from } \\
\text { experienced teachers are } \\
\text { important for me. }\end{array}$ & 4.82 & .44 & & \\
\hline & Community involvement & 4.39 & .64 & 1.15 & 12.82 \\
\hline & $\begin{array}{l}\text { - I find it convenient to } \\
\text { have a discussion about } \\
\text { my teaching with my } \\
\text { colleagues at my } \\
\text { institution. }\end{array}$ & 4.02 & .72 & & \\
\hline & $\begin{array}{l}\text { I feel I need to do } \\
\text { collaborative teaching } \\
\text { projects with other fellow } \\
\text { teachers (e.g. research, } \\
\text { workshop). }\end{array}$ & 4.44 & .62 & & \\
\hline & $\begin{array}{l}\text { I feel the need as teachers } \\
\text { to contribute to their } \\
\text { community through } \\
\text { sharing sessions or other } \\
\text { possible opportunities. }\end{array}$ & 4.64 & .53 & & \\
\hline & $\begin{array}{l}\text { - I feel the need to actively } \\
\text { participate in professional } \\
\text { teaching associations or } \\
\text { communities (e.g. } \\
\text { TEFLIN, MGMP) }\end{array}$ & 4.44 & .69 & & \\
\hline
\end{tabular}

As pinpointed in Table 4, one can notice how the campers' perceptions became comparatively more positive after the program. The PCA shows that the reflection component can be categorized into two factors: job-motivation $(\bar{x}=$ $4.53, \mathrm{SD}=.60)$ and reflective skills $(\bar{x}=4.46, \mathrm{SD}=.60)$, the value of which suggests that the pre-service teachers possess a relatively high level of motivation for their job and willingness to reflect on their competence after joining the program. Having approximately the same average, the sub-scale integration can be observed through two factors: personal characteristics $(\bar{x}=$ $4.60, \mathrm{SD}=.53)$ and professional traits $(\bar{x}=4.37, \mathrm{SD}=.68)$. Based on the values, 
it can be deduced that the respondents believe Camp EPIC has helped them nurture personal and professional traits in their teacher identity. The variable of adaptability, which is the lowest indicator, illustrates an intriguing pattern of factors, although the means generally show a positive perception. While the campers claimed to know how to adopt different teaching methodologies for various materials $(\bar{x}=4.12, \mathrm{SD}=.72)$, they exhibited relatively lower perception value in the way they interacted with others (e.g. students or colleagues) $(\bar{x}=$ $3.71, \mathrm{SD}=.75)$, and the way they fit in diverse teaching contexts (e.g. culture, conflicts or tensions) $(\bar{x}=3.85, \mathrm{SD}=.63)$. Lastly, the sub-scale of active participation demonstrates that Camp EPIC spurs them to actively seek for learning resources $(\bar{x}=4.61, \mathrm{SD}=.61)$ and get involved in wider teaching communities $(\bar{x}=4.39, \mathrm{SD}=.64)$.

\section{Features of Camp EPIC}

The previous findings are an indication that the program took effect to some extent. It is also worth looking into the notable features of the program that had the most significant impact on these changes. Based on the coding of the openended questions, some sessions in Camp EPIC are found to be more salient than the others, as shown in Table 5.

Table 5. Summary of Respondents' Perceptions about the Camp Sessions

\begin{tabular}{|c|c|c|c|c|c|}
\hline 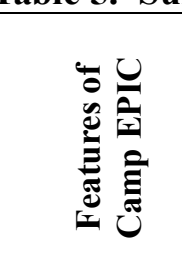 & 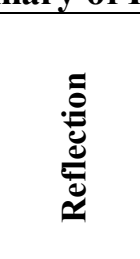 & & 产 & 苞 & 吾 \\
\hline $\begin{array}{l}\text { Modelling } \\
\text { teaching }\end{array}$ & $\begin{array}{c}30 \\
(66.7 \%)\end{array}$ & $\begin{array}{c}22 \\
(48.9 \%)\end{array}$ & $\begin{array}{c}11 \\
(24.4 \%)\end{array}$ & $\begin{array}{c}16 \\
(35.6 \%)\end{array}$ & $\begin{array}{l}\text { Various teaching } \\
\text { materials; chance to } \\
\text { learn from others; } \\
\text { chance to evaluate } \\
\text { oneself based on } \\
\text { others' teaching }\end{array}$ \\
\hline
\end{tabular}




\begin{tabular}{|c|c|c|c|c|c|}
\hline 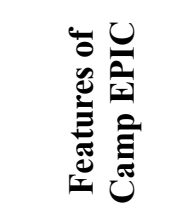 & 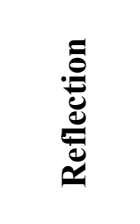 & 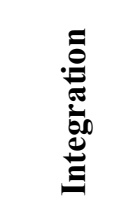 & 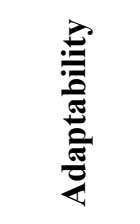 & 突 & 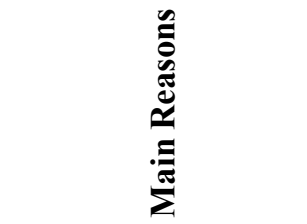 \\
\hline $\begin{array}{l}\text { Group } \\
\text { micro- } \\
\text { teaching }\end{array}$ & $\begin{array}{c}30 \\
(66.7 \%)\end{array}$ & $\begin{array}{c}28 \\
(62.2 \%)\end{array}$ & $\begin{array}{c}15 \\
(33.3 \%)\end{array}$ & $\begin{array}{c}20 \\
(44.4 \%)\end{array}$ & $\begin{array}{l}\text { Enhancing teaching } \\
\text { ability; nurturing } \\
\text { personal competence } \\
\text { (confidence, } \\
\text { enthusiasm); chance } \\
\text { to receive } \\
\text { constructive } \\
\text { feedback; self- } \\
\text { evaluation }\end{array}$ \\
\hline $\begin{array}{l}\text { Collaborativ } \\
\text { e lesson } \\
\text { planning }\end{array}$ & $\begin{array}{c}22 \\
(48.9 \%)\end{array}$ & $\begin{array}{c}20 \\
(44.4 \%)\end{array}$ & $\begin{array}{c}26 \\
(57.8 \%)\end{array}$ & $\begin{array}{c}11 \\
(24.4 \%)\end{array}$ & $\begin{array}{l}\text { Adapting to diverse } \\
\text { materials/methodolog } \\
\text { ies; dealing with } \\
\text { different/conflicting } \\
\text { opinions; engaging in } \\
\text { intercultural } \\
\text { exchange }\end{array}$ \\
\hline $\begin{array}{l}\text { Expert } \\
\text { sharing }\end{array}$ & $\begin{array}{c}7 \\
(15.6 \%)\end{array}$ & $\begin{array}{c}10 \\
(22.2 \%)\end{array}$ & $\begin{array}{c}5 \\
(11.1 \%)\end{array}$ & $\begin{array}{c}23 \\
(51.1 \%)\end{array}$ & $\begin{array}{l}\text { Exposure to wider } \\
\text { teaching } \\
\text { communities; } \\
\text { expanding teaching } \\
\text { network }\end{array}$ \\
\hline
\end{tabular}

As seen in Table 5, there were four major activities that they found four activities most beneficial for their development as English teachers, namely, modelling teaching, group micro-teaching, collaborative lesson planning, and expert sharing. The campers also listed the reasons why these four activities were advantageous for their development as English teachers.

The first component that the participants pointed out is modelling teaching, which is particularly high in terms of how they practice reflective skills $(66.7 \%)$. Regarding this, some of them predominantly mentioned: "knowing various ways to teach innovatively" (S4) and "getting new perspectives from expert 
facilitators" (S25, S45). As an illustration, S16 shared her learning experience wherein she "got many new methods and techniques such as running dictation which the facilitator taught in speaking model lesson."

They also stated that they could have the chance to compare their previous teaching practice with that of the model teachers in Camp EPIC, thus allowing them to reflect on themselves continuously. S27 detailed her reflective process as follows.

The moments brought me to think deeper about what is going on with my teaching, what I still need to improve, what I should avoid, and what I should imitate from the facilitators when teaching (S27).

These in turn helped them garner a wide range of teaching materials and methodologies for any class purposes. Aptly condensing most of the responses, S5 provided insights on the merit of the session.

When I saw and took a role as a student in modelling teaching, I could feel how excited I was, how I understood the materials, and so on. Then, I could evaluate myself and compare it to how I used to teach my students in class (S5).

The next session with notable advantages is group micro-teaching in that it assists campers in fostering their skills and evaluating their performance $(66.7 \%)$ and in their becoming a teacher with decent personal and professional qualities $(62.2 \%)$. Many campers pointed out that they were given opportunities to reflect and learn from constructive feedback given by the facilitators, counsellors, peers, and even themselves. Accordingly, by engaging directly in such practice, they saw their confidence as teachers rise along with their belief in their teaching competence as asserted by S10, who reflected on the importance of feedback.

After the presentation, we got feedback from counsellors and facilitators. They gave positive feedbacks to our teaching practice. Automatically, it will motivate me to develop myself and improve my teaching experiences in many places. So, it will be easier to reach my dream as a professional lecturer (S10).

Still related to the previous two activities, collaborative lesson planning is also a notable session because it provides campers chances to adapt to different teaching situations $(57.8 \%)$. S17 summarized what she felt about the session.

In this activity, we should make up our mind to choose the students' level and the appropriate material that we should give. I learn how to adapt as well as I can so 
we came up with the final decision agreed on by everyone in the teaching team (S17).

In particular, this session made them readier to deal with conflicting ideas or goals of their peers or colleagues during the lesson planning process, including what materials or methodologies to use in their micro-teaching. Also, they principally became more aware that teaching should be adjusted based on each circumstance of classroom, school, or culture through the intercultural exchange of ideas among themselves as they originated from different regions of Indonesia. S20 explained the process of this collaborative lesson planning:

In the process of making lesson-plan, there were a lot of thoughts and ideas about which teaching methods that we will use in micro teaching session. Sometimes, it is difficult to adapt to new teaching methods that we never heard, yet each member of the team including me tried to adapt well. Camp EPIC really trains me to adapt easily to both the new environment and new teaching methods that any schools are using nowadays (S20).

Finally, the campers believed that expert sharing sessions were also fruitful as these helped them reach out to a broader range of teacher communities across the country $(51.1 \%)$. Upon listening to this sharing, the campers felt more motivated to get involved in more teacher development activities such as workshops or online courses for teachers. In line with others, S29 expounded on what he was eager to do after the camp:

The camp also allowed me to join IMOOC (Indonesian Massive Open Online Course) and conduct sharing sessions. With the learning resources the camp provided, I have many things to explore and try (S29).

Additionally, they were made aware of the need to expand their teaching network by collaborating with other fellow teachers or EFL counterparts. Such observation was apparent in the answer given by $\mathrm{S} 1$ :

It (the sharing session) gave a clear prospect that how connection can create better things - not only for individual but also for the group/community you live in (S1).

\section{Discussion}

The findings show that there is a positive change in the way the camp participants perceive their identities as English teachers after they attended the program, meaning that the outcomes of the program resonate with its main goals. 
Such change is justified by the campers' more positive post-camp perceptions vis-à-vis their pre-camp self-description, which generally shows the campers' initial doubt about their competence as teachers.

Prior to participating in Camp EPIC, most campers exhibited low perception of their pedagogical skills (e.g., teaching ideas, classroom management), although most of them mentioned having had previous teaching experience. This low perception can be attributed to the notion that teacher's professional identity construction can become fragile as they are exposed to the complexity of real teaching practice (Lamote \& Engels, 2010). As they indulge in school classrooms, their actual teaching performance often does not conform to their expectations of how they should teach, leading to the so-called "reality shock" that results in a waning sense of professional identity.

Furthermore, it can also clarify why many campers stated that they were not well-equipped with adequate teaching resources and strategies, believing they were prone to being "unprepared" throughout their teaching experience. Such findings are in concert with Pendergast et al. (2011), who found out that preservice teachers would more likely demonstrate a lower level of self-efficacy in their teaching as they gained more understanding of practical teaching situations. Such a low rate of confidence can also be caused by the surroundings where the pre-service teachers had ever taught because teacher identity is a dynamic and context-dependent notion (Riyanti, 2017). Therefore, it seemed that these preservice English teachers' identities were not firmly formed even after they had almost finished their study, and joining Camp EPIC could contribute to shaping how they perceive themselves as EFL professionals.

The campers experienced changes in their perception, seeing the generally positive responses in their post-camp perception. These positive changes concern the many aspects of their identity, such as job motivation, willingness to reflect and learn, self-efficacy, and sense of preparedness to immerse in actual teaching contexts. Viewing these changes from the tenets of situated learning (Lave \& Wenger, 1991) - which state that learning inherently concerns the whole person in relation to their participation in social communities - the construction of professional identity among the campers appears to be pertinent to their participation in Camp EPIC, which is a form of communities of practice. The program served as a departure point from which the participants started experiencing "an evolving form of membership" (p. 53) from being newcomers who learned from the program facilitators during the program to becoming old- 
timers who could share their knowledge with their own communities of teachers. The program has led the campers to realize that their learning results not only from their mastery of knowledge, but also from their involvement in creating communities of practice in their respective regions.

Nonetheless, given the short period of the program, it is worth noting that the merits of a teacher camp may not be sustainable if conducted discretely from a more systematic teacher education program. What is then important is how the tacit values of the teacher camp can be integrated into teacher education courses. In line with Wenger's (2000) dimensions of communities of practice, it is recommended that teacher training programs can manifest the four features present in Camp EPIC: reflective practices, constructive feedback, resourceful practices, and collaboration.

Wenger (2000) mentions enterprise as one essential component of communities of practice, referring to learners' initiative to learn with a spirit of inquiry concerning gaps in their knowledge and to remain open to emergent learning opportunities. Addressing this need, Camp EPIC encouraged its participants to engage in reflective practices, particularly during the main activities such as modelling teaching and micro-teaching. In the modelling teaching, the campers were given opportunities to learn from how both native and non-native English teachers performed and relate these to their own teaching experiences. Observing the models who were experienced ESL/EFL teachers, they were expected to not only imitate them but also adopt teaching practices following their own teaching contexts. Through self-monitoring, the campers were made aware of who they are as EFL practitioners, and they were also motivated to continuously develop themselves as English teachers despite being in the embryonic stage of their teaching career. In the university contexts, the practice can be extended to written self-reflection in the form of lesson reports and journal writing or oral reflection in the form of self-talk or audio/video recording (Farrell, 2015).

Equally crucial concerning reflective practice is the provision of constructive feedback, which can be a form of joint inquiry (Wenger, 2000), whereby learners can cooperate to identify and address gaps in their professional practice. Besides giving themselves self-feedback of the teaching performance during the micro-teaching sessions, the campers likewise received supportive yet meaningful feedback from the camp facilitators or teaching peers. Pre-service teachers expect feedback that has a proportional balance between positive 
reinforcement and areas for improvement. Effective mentor feedback can eventually lead to the improvement of the self-efficacy of the young teachers (Lamote \& Engels, 2010) and promote their identity as reflective teachers. What is more, the feedback is provided in a relatively relaxed setting, implying that the camp gives the participants time to build an emotionally closer relationship with other fellow teachers or experts. This type of setting is similar to the language immersion camp described in the study of Wighting et al. (2006), where students improved their language skills because they felt it more convenient to interact with their peers or even teachers.

Another essential feature is how Camp EPIC spurred its participants to become resourceful with teaching materials that they either received or developed throughout all the program's sessions. In other words, the campers were encouraged to use or produce a repertoire of artefacts relevant to their work (Wenger, 2000), for example, lesson plans, syllabi, teaching aids, reflective notes, teaching videos, or websites. During the camp, the pre-service teachers were assisted in exploring and using a wide range of teaching resources effectively, either individually or collaboratively. Correspondingly, the participants have garnered more learning resources for their future professional development, such as opportunities to join workshops or attend open online courses. It manifests one of the program's goals, which is to nurture wellprepared teachers because a sense of preparedness is a significant indicator of their self-efficacy and professional orientation when they start their real work (Schepens et al., 2009).

Lastly, just as communities of practice promote mutuality among the members (Wenger, 2000), Camp EPIC likewise endorses collaborative practices among its participants. In its implementation, student teachers had the opportunities to share insights about each other's teaching experiences, performances, or even cultures in their respective regions. They were trained to be more open-minded to embrace different or conflicting ideas during teamwork activities. For instance, in the collaborative lesson planning, a group of campers finally decided upon what activities they should perform in the micro-teaching sessions. Throughout the process, they frequently had to haggle over which materials or methods worked best by bringing along their previous teaching knowledge and background. They talked about how one method could work in one teaching culture but not in the other. In principle, this intercultural exchange (Walters et al., 2009) is believed to enhance their skills in dealing with diverse 
students or colleagues-hence their adaptability. What is more, such collaboration can extend to the practice of critical friendships (Farrell, 2015), where young teachers give each other advice about their teaching performances. They can exchange expertise, resources, and knowledge that are beneficial for their classroom purposes. When teachers engage in these activities, the goal to create a teacher's community where everyone strives to grow professionally together as educators is indeed viable.

\section{CONCLUSIONS}

The present study has shown how a teacher camp can contribute to the process of identity construction of pre-service teachers in Indonesia. In line with its acronym of EPIC, Camp EPIC has the potential to empower the participating pre-service teachers to become more reflective and motivated, prepare them with more teaching resources, inspire them to become confident teachers and connect them into one bigger community of teachers. Thus, their professional identity as EFL educators can be positively influenced, which is expected to lead to the betterment of their teaching practice in their institutions.

In practice, Camp EPIC can function as a model for teacher educators intending to conduct a similar program, namely the one designed for student teachers in their last years of study. As demonstrated earlier, a teacher camp has the role to aid the transitional phase of pre-service teachers from being mere learning teachers to actual practicing teachers. Moreover, it prepares them to become familiar with not only how to improve language and pedagogical knowledge but also how to get more involved in their own professional development. That said, the potential of Camp EPIC cannot be overlooked by teacher education stakeholders.

Nevertheless, as the current study examines only one specific program that is brief and discrete in nature, it should be acknowledged that the study does not entail the idea that Camp EPIC has entirely succeeded in shaping the participants' professional identity. Given the complex nature of professional identity construction, on no account do the findings attempt to prove that the program leads to a sustainable long-term impact on the process of identity construction. Rather, the present study shows how the values and best practices within the program can contribute to future teacher education practice, particularly at pre-service level. 
It is therefore intriguing to explore how the concept of teacher camps can be incorporated into a larger system of any pre-service teacher education courses and how it influences the identity formation over a longer study period. The adaptation per se does not necessarily need to be in the form of exact replication. When the notion of replicating the same program might not be feasible in some contexts due to practical issues (e.g. budget, human resources), teacher educators are encouraged to implement its more particular features like reflective and collaborative practices in the teacher education programs at their institutions. They can in fact come up with their own innovative programs or ways as long as the core ideals of professional identity are not neglected. These values of reflection, resourceful practices, and collaboration in Camp EPIC can be applied and expanded based on the need of each teacher and their institution. The main point is that teacher development programs should strive to produce highly qualified language teachers with solid professional identity, and in the end, it is always the students' learning process that benefits the most from the employment of effective teachers.

\section{REFERENCES}

Abednia, A. (2012). Teachers' professional identity: Contributions of a critical EFL teacher education course in Iran. Teacher and Teacher Education, 28(5), 706-717. https://doi.org/10.1016/j.tate.2012.02.005

Afrianto. (2015). Constructing professional identity through teaching practicum: An Indonesian case study of pre-service teachers [Doctoral dissertation, Monash University, Australia]. https://doi.org/10.4225/03/58b626377b653

Ahmad, H., Latada, F., Wahab, M. N., Shah, S. R., Khan, K. (2018). Shaping professional identity through professional development: A retrospective study of TESOL professionals. International Journal of English Linguistics, 8(6), 37-51. https://doi.org/10.5539/ijel.v8n6p37

Beijaard, D., Maijer, P. C., \& Verloop, N. (2004). Reconsidering research on teachers' professional identity. Teacher and Teacher Education, 20(2), 107128. https://doi.org/10.1016/j.tate.2003.07.001

Beijaard, D., Verloop, N., \& Vermunt, J. D. (2000). Teachers' perceptions of professional identity: An exploratory study from a personal knowledge perspective. Teaching and Teacher Education, 16(7), 749-764. https://doi.org/10.1016/S0742-051X(00)00023-8 
Braun, V., \& Clarke, V. (2006). Using thematic analysis in psychology. Qualitative Research in Psychology, 3(2), 77-101. https://doi.org/10.1191/1478088706qp063oa

Canrinus, E.T., Helms-Lorenz, M., Beijaard, D., Buitink, J., \& Hofman, A. (2011). Profiling teachers' sense of professional identity. Educational Studies, 37(5), 593-608. https://doi.org/10.1080/03055698.2010.539857

Coldron, J. \& Smith, R. (1999). Active location in teachers' construction of their professional identities. Journal of Curriculum Studies, 31(6), 711-726. https://doi.org/10.1080/002202799182954

Creswell, J.W. (2011). Educational research: Planning, conducting and evaluating quantitative and qualitative research $\left(4^{\text {th }}\right.$ ed.). Pearson Education.

Day, C. (2012). New lives of teachers. Teacher Education Quarterly, 39(1), 726. https://files.eric.ed.gov/fulltext/EJ977354.pdf

Farrell, T. S. C. (2015). Language teacher professional development. TESOL Press.

Field, A. (2009). Discovering statistics using SPSS ( $3^{\text {rd }}$ ed.). Sage Publication.

Hair, J. F., Black, W. C., Babin, B. J., \& Anderson, R. E. (2014). Multivariate data analysis $\left(7^{\text {th }}\right.$ ed.). Pearson Education Limited.

Irani, F. H., Chalak, A. \& Tabrizi, H. H. (2020). Assessing pre-service teachers' professional identity construction in a three-phase teacher education program in Iran. Asian-Pacific Journal of Second and Foreign Language Education, 5, Article number: 19. https://doi.org/10.1186/s40862-02000100-3

Kudaibergenov, M., \& Lee, K. (2020). Professional identity tensions in Korean EFL student teachers: A reflective journal analysis. The Journal of Asia TEFL, 17(2), 414-427. http://dx.doi.org/10.18823/asiatefl.2020.17.2.7.414

Lamote, C., \& Engels, N. (2010). The development of student teachers' professional identity. European Journal of Teacher Education, 33(1), 3-18. https://doi.org/10.1080/02619760903457735

Lave, J., \& Wenger, E. (1991). Situated learning: Legitimate peripheral participation. Cambridge University Press.

Lomi, A. N. K., \& Mbato, C. L. (2020). Struggles and strategies in constructing professional identity: The first-year teaching experiences of Indonesian EFL novice teachers. Journal of English Education and Teaching (JEET), 4(1), 1-19. https://doi.org/10.33369/jeet.4.1.1-19 
Pendergast, D., Garvis, S., \& Keogh, J. (2011). Pre-service student-teacher selfefficacy beliefs: An insight into the making of teachers. Australian Journal of Teacher Education, 36(12), 46-58. http://dx.doi.org/10.14221/ajte.2011v36n12.6

Pop, R. (2015). Understanding pre-service trainees' perceptions of their teacher training experience. Procedia - Social and Behavioral Sciences, 209, 378382. https://doi.org/10.1016/j.sbspro.2015. 11.207

Riyanti, D. (2017). Teacher identity development: A collective case study of English as a foreign language pre-service teachers learning to teach in an Indonesian university teacher education program [Doctoral dissertation, University of Nebraska-Lincoln, Lincoln, Nebraska, USA]. https://digitalcommons.unl.edu/cehsdiss/289/

Rugasken, K., \& Harris, J. A. (2009). English camp: A language immersion program in Thailand. TLAR, 14(2), 43-51. https://files.eric.ed.gov/fulltext/EJ866925.pdf

Sarani, A., \& Najjar, R. (2013). Formulation of language teachers' identity in the situated learning of language teaching community of practice. Iranian Journal of Applied Language Studies, 5(2), 167-192. https://doi.org/10.22111/IJALS.2015.1882

Sardabi, N., Biria, R., \& Golestan, A. A. (2018). Reshaping teacher professional identity through critical pedagogy-informed teacher education. International Journal of Instruction, 11(3), 617-634. https://doi.org/10.12973/iji.2018.11342a

Schepens, A., Aelterman, A., \& Vlerick, P. (2009). Student teachers' professional identity formation: Between being born as a teacher and becoming one. Educational Studies, 35(4), 361-378. https://doi.org/10.1080/03055690802648317

Stronge, J. H. (2007). Qualities of an effective teacher. Association for Supervision and Curriculum Development.

Stronge, J. H., Ward, T. J. \& Grant, L. W. (2011). What makes good teachers good? A cross-case analysis of the connection between teacher effectiveness and student achievement. Journal of Teacher Education, 62(4), 339-355. https://doi.org/10.1177/ 0022487111404241

Walters, L. M., Garii, B., \& Walters, T. (2009). Learning globally, teaching locally: Incorporating international exchange and intercultural learning into 
242 TEFLIN Journal, Volume 32, Number 2, July 2021

pre-service teacher training. Intercultural Education, 20(1-2), S151-S158. https://doi.org/10.1080/14675980903371050

Wenger, E. (2000). Communities of practice and social learning systems. Organization, 7(2), 225-246. https://doi.org/10.1177/135050840072002

Wighting, M. J., Nisbet, D. L., \& Tindall, E. R. (2005). Exploring a summer English language camp experience in China: A descriptive case study. Asian EFL Journal, 7(4), 1-26. http://asian-efl-journal.com/pta_feb_06_mw.pdf 